\title{
Selected findings from parametric studies determining the resistance of concrete panels in real terms
}

\author{
Iveta Hegedüsová, Peter Sabol, Sergej Priganc \\ Technical University of Košice \\ Civil Engineering Faculty, Institute of Structural Engineering \\ e-mail:iveta.hegedusova@tuke.sk, peter.sabol@tuke.sk, sergej.priganc@tuke.sk
}

\begin{abstract}
In the article selected results of parametric analysis of lightened reinforced concrete panels used in agricultural objects are presented. The aim of the analysis was to devise a parametric model that can be later on used for the simulation of behaviour of real ceiling panels when changing pre-defined parameters.
\end{abstract}

Key words: concrete, steel reinforcement, ceiling panel, agricultural structure K-174, deflection, crack, parametric analysis.

\section{Introduction}

A change in the political regime in the 1990s led to a change in ownership relationships, including the ones in agricultural farming production. Nowadays, conditions of cattle breeding agricultural structures in Slovakia are considered unsatisfactory, both from operation and, to a large extent, static points of view. The structures serve their purpose despite their conditions and they can be assumed a threat not only to the livestock but to the staff as well. Therefore, it is important to look into this serious problem, it is inevitable to carry out regular inspections in the structures, and based on their results, to decide whether the structure is eligible for reconstruction or it is more appropriate for the structure to get demolished. The stable structures serviceability is mainly affected by the aggressive cow barn environment, so called cow barn microclimate, characterized by an excessive presence of harmful gases (hydrogen sulphate, ammonia, and carbon dioxide), dustiness, and humidity. A negative impact of these factors onto a structure is manifested by its degradation, while ceiling panels occur to be the most affected elements. During their production, regarding economy, they were preferred to be light and thin which has now resulted in a faster onset of the degradation process manifesting itself by the covering concrete layer fallen down, and concrete and reinforcement corrosions [2]. 


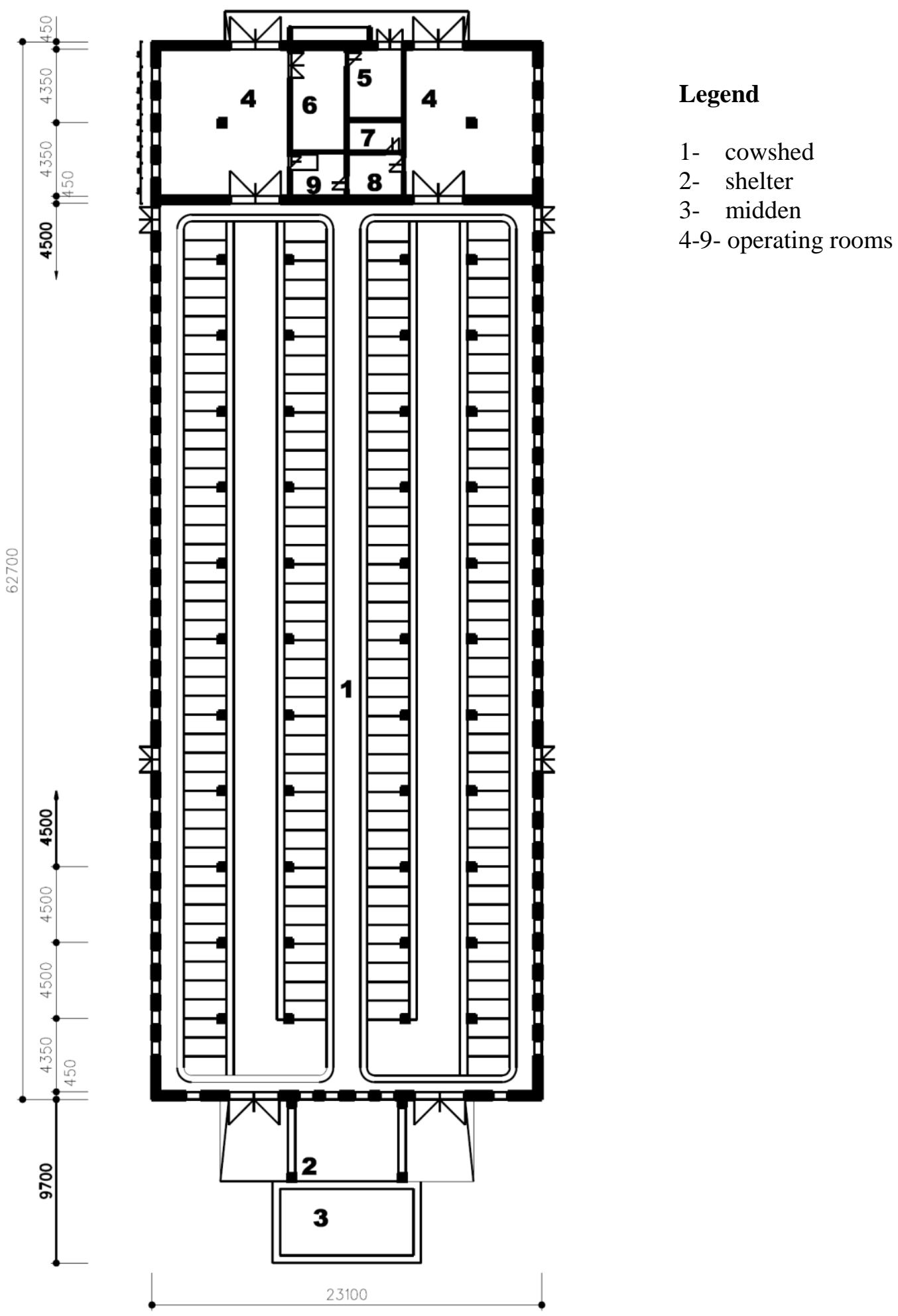

Figure 1: Object K - 174 


\section{Description of the object}

The subject matter of the article is to analyze and evaluate ceiling panels conditions in the real environment of the cow barns of K-174 type (Fig. 1). This type of an agricultural structure is a standard representative of large capacity cow barns. The structure forms a separate closed technological operational livestock farming unit to stable 174 pieces of dairy cows [1].

\subsection{Design considerations of concrete building structure}

The subject matter is a general-purpose reinforced concrete prefabricated structure, combined with external load-bearing brick walls, and no loft (Fig. 2). It is a single-storey transit building built as a 5-nave structure with four longitudinal prefabricated reinforced concrete frames. The system altogether comprises ten elements, assembled as single-storey structures with cantilevered columns, single beams, and single embedded ceiling panels. The roof structure gradient is $10^{\circ}$. Module axes are spaced by $4500 \mathrm{~mm}$ and $6000 \mathrm{~mm}$. The cow barn roof bearing structure consists of lightened ribbed reinforced concrete ceiling panels marked as SZD 10n - 450 (Fig. 3).

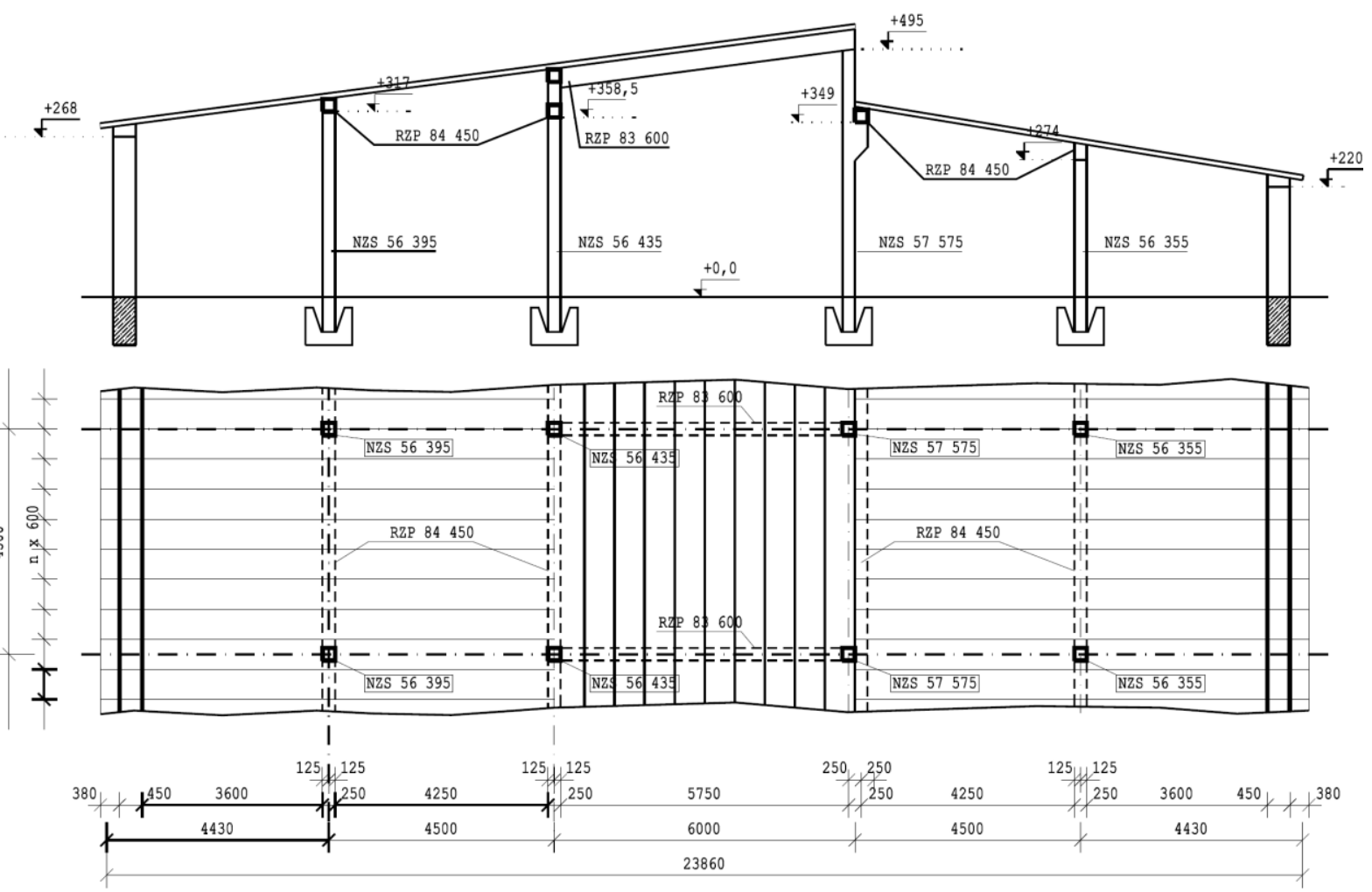

Figure 2: Scheme of composition of the object K - 174 


\subsection{The choice of carrying element for parametric study}

As the subject matter of the study, we have chosen the most exposed element - a lightened panel (Fig. 3). Longitudinal panel ribs contain the main load-bearing longitudinal reinforcement (one stiffening rod of $8 \mathrm{~mm}$ in diameter) (Fig. 4). The reinforcement is anchored by cohesion or is welded to the transverse bars (of $6 \mathrm{~mm}$ in diameter). The panels were produced from concrete with strength of $25 \mathrm{MPa}$, the main load-bearing reinforcement used was of $350 \mathrm{MPa}$ in strength, while the structural reinforcement was of $200 \mathrm{MPa}$ in strength.
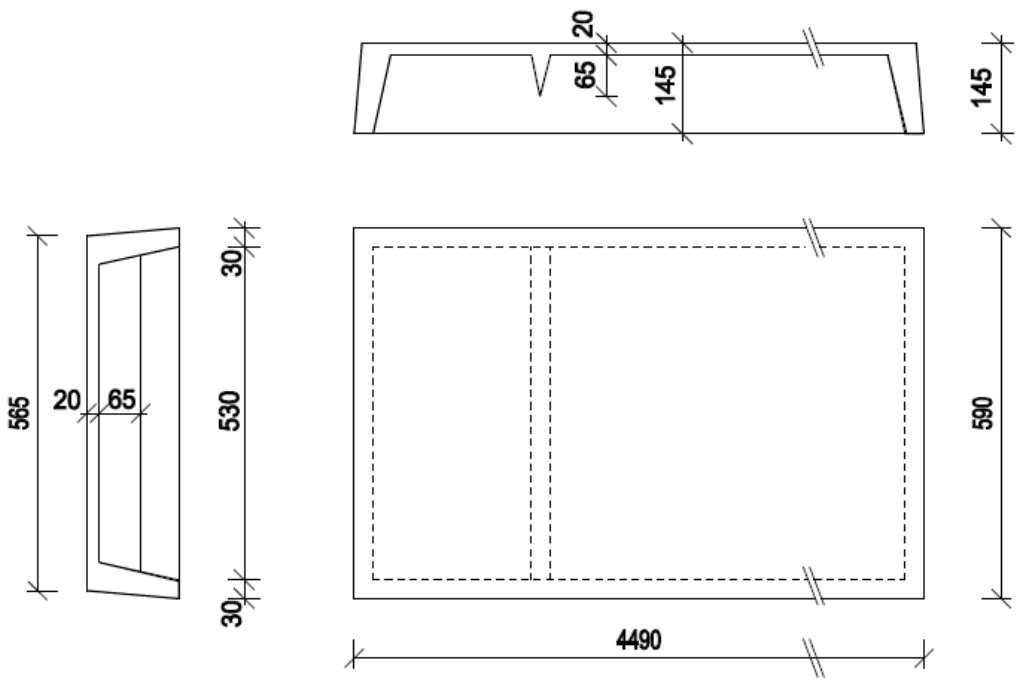

Figure 3: Concrete roof panel SZD 10n-450

\section{Parametric analysis}

The analysis was aimed at designing such parametric models that could be used to simulate ceiling panels behaviour while changing chosen parameters under real conditions. For the purpose of the parametric analysis we used ATENA V4 software [3] which is based on the finite element method.

\subsection{Modelling and calculation}

Modelling of the chosen task was carried out in a pre-processing phase during which an input file was created in GiD software environment: element geometry, material characteristics editing, grid formation, setting calculation parameters and boundary conditions. In this mode, so-called monitors, recording measured parameters, deflections and cracks, were set in specified monitored spots on the panel. Static tasks were modelled in Static software.

Loading was carried out by an increase in surface load, applied in partial values in a set number of steps. A hexagonal prism - Hexahedra element - was a preferred type of a finite 
element. Therefore, the grid was formed by means of Hexahedra elements. To solve the task, we have chosen Newton-Raphson iteration method which is based on the principle of estimating a solution for unknown values and, in the following step, accuracy improvement for the previous solution is made. The correction process is repeated until the solution inaccuracy in individual iterations reaches a specified inaccuracy value [3].

Longitudinal section

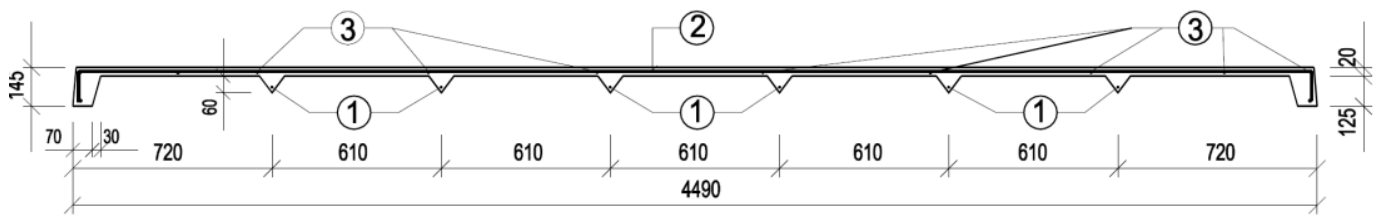

Ground plan

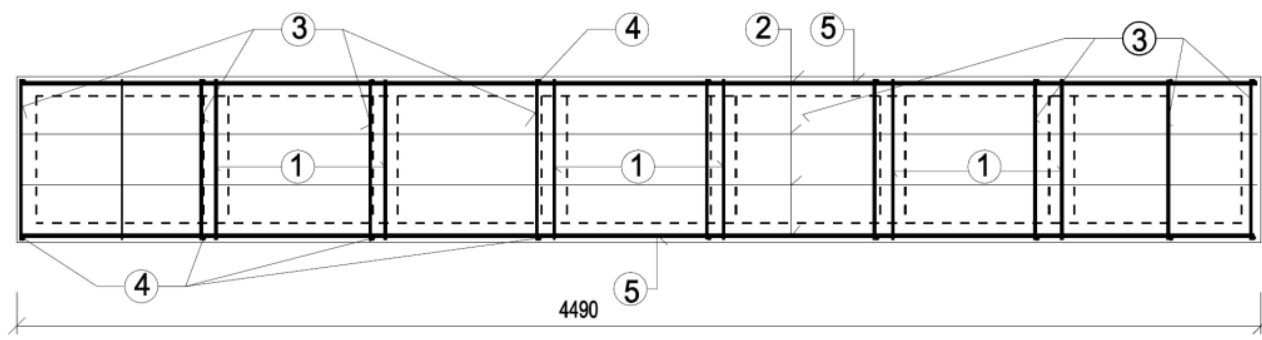

Section A-A

Section B-B'

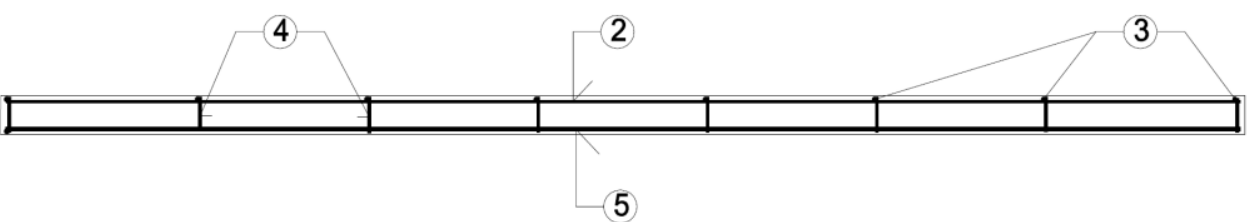

1-4 - structural reinforcement 5 - tensile reinforcement

Figure 4: Scheme of reinforcement panel

The parametric model copied real dimensions and characteristics of the ceiling panel components, though transverse panel ribs were modified which led to a significant elimination of the number of necessary elements, and thus to the grid topography simplification. Altogether, the model comprised three types of materials, namely concrete, reinforcement, and a steel board which was used as a load spreading board at panel supporting areas to avoid local concrete failures at linear supports. The concrete model was set by SOLID Concrete material group, while a specific material, Cementitious 2 (CC3DNonLinCementitious), combining basic models for tension and compression behaviour of concrete, was chosen [4]. The strength set by the design was $25 \mathrm{MPa}$ and the measured strength was 23 and $21 \mathrm{MPa}$. The longitudinal tension reinforcement, and both strap and structural reinforcements were modelled as discrete 1D reinforcements, set by 1D Reinforcement - CCReinforcement material. In the analysis, the original $8 \mathrm{~mm}$ diameter of the longitudinal reinforcement, a presumed decreased $7 \mathrm{~mm}$ diameter (due to reinforcement 
corrosion), and an added $10 \mathrm{~mm}$ diameter (due to a substitution in some of the panels) were used. Material characteristics are presented in Table 1.

Table 1: Material characteristics for parametric simulation

\begin{tabular}{|l|l|c|c|c|}
\cline { 2 - 5 } \multicolumn{1}{c|}{} & $\mathrm{f}_{\mathrm{c}, \text { cube }}[\mathrm{MPa}]$ & 25 & 23 & 21 \\
\hline \multirow{3}{*}{ Concrete } & $\mathrm{f}_{\mathrm{c}}[\mathrm{MPa}]$ & 21 & 19 & 17 \\
\cline { 2 - 5 } & $\mathrm{f}_{\mathrm{t}}[\mathrm{MPa}]$ & 2,301 & 2,180 & 2,050 \\
\cline { 2 - 5 } & $\mathrm{E}_{\mathrm{c}}[\mathrm{GPa}]$ & 28,062 & 27,065 & 26,003 \\
\hline \multirow{5}{*}{ Reinforcement } & $\varnothing[\mathrm{mm}]$ & 8 & 10 & 7 \\
\cline { 2 - 5 } & $\mathrm{f}_{\mathrm{sy}}[\mathrm{MPa}]$ & 350 & 350 & 350 \\
\cline { 2 - 5 } & $\mathrm{E}_{\mathrm{s}}[\mathrm{GPa}]$ & 200 & 200 & 378 \\
\cline { 2 - 5 } & $\mathrm{f}_{\mathrm{st}}[\mathrm{MPa}]$ & 378 & 378 & 200 \\
\hline
\end{tabular}

Legend:

$\mathrm{f}_{\mathrm{c}, \text { cube }}$ - cube strength of concrete

$\mathrm{f}_{\mathrm{c}} \quad$ - cylinder strength of concrete

$\mathrm{f}_{\mathrm{t}} \quad$ - tensile strength of concrete

$\mathrm{E}_{\mathrm{c}} \quad$ - elastic modulus of concrete

$f_{s y} \quad$ - strength of reinforcement (yield strength steel)

$\mathrm{E}_{\mathrm{s}} \quad$ - elastic modulus of reinforcement

$\mathrm{f}_{\text {st }} \quad$ - tensile strength of reinforcement $-\mathrm{f}_{\mathrm{sy}} \cdot \mathrm{k}(\mathrm{k}=1,08)$

The last variable parameter in the analysis was the concrete covering, i.e. the original designed value $10 \mathrm{~mm}$ and values found out by examination, 20 and $30 \mathrm{~mm}$. For the parametric study we prepared 27 panels (beams) labelled as NVK (beam / reinforcement / concrete covering). The list of the panels with input parameters is shown in Table 2.

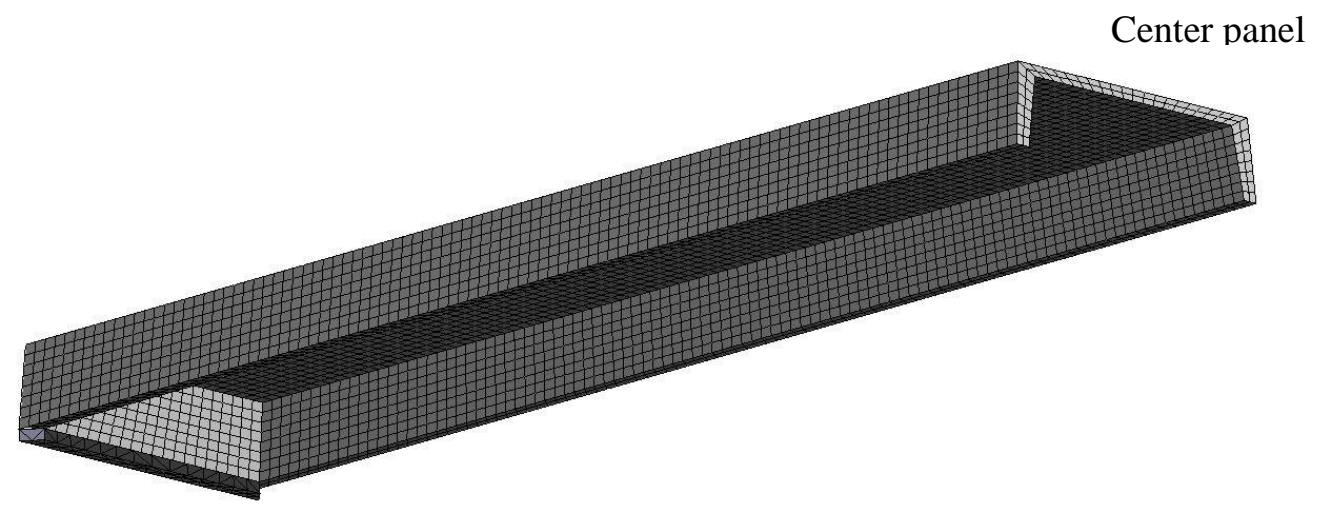

Figure 5: Model of panel 
Due to symmetry, it was sufficient to model only a half of the panel which decreased the calculation time. A parametric model of a panel shaped as a finite element grid is shown in Fig. 5.

\subsection{Parametric simulation of panel action}

Behaviour of the panel obtained from the parametric simulation is presented by a deflectionload ratio and crack topography. Fig. 6 shows a demonstration of panel deformation with recorded deflection values, while Fig. 7 presents the crack topography. A half of the panel is presented.

Table : 2 Input parametes of panel

\begin{tabular}{|c|c|c|c|}
\hline \multicolumn{4}{|c|}{ Input parametes } \\
\hline Panel labelling & $\begin{array}{c}\text { Concrete fck cube } \\
{[\mathrm{MPa}]}\end{array}$ & $\begin{array}{c}\text { Reinforcement } \\
\text { diameter } \varnothing[\mathrm{mm}]\end{array}$ & $\begin{array}{c}\text { Concrete cover } \\
{[\mathrm{mm}]}\end{array}$ \\
\hline N1V1K1 & 25 & 8 & 10 \\
\hline N1V1K2 & 25 & 8 & 20 \\
\hline N1V1K3 & 25 & 8 & 30 \\
\hline N1V2K1 & 25 & 10 & 10 \\
\hline N1V2K2 & 25 & 10 & 20 \\
\hline N1V2K3 & 25 & 10 & 30 \\
\hline N1V3K1 & 25 & 7 & 10 \\
\hline N1V3K2 & 25 & 7 & 20 \\
\hline N1V3K3 & 25 & 7 & 30 \\
\hline $\mathrm{N} 2 \mathrm{~V} 1 \mathrm{k} 1$ & 23 & 8 & 10 \\
\hline $\mathrm{N} 2 \mathrm{~V} 1 \mathrm{~K} 2$ & 23 & 8 & 20 \\
\hline $\mathrm{N} 2 \mathrm{~V} 1 \mathrm{~K} 3$ & 23 & 8 & 30 \\
\hline $\mathrm{N} 2 \mathrm{~V} 2 \mathrm{~K} 1$ & 23 & 10 & 10 \\
\hline $\mathrm{N} 2 \mathrm{~V} 2 \mathrm{~K} 2$ & 23 & 10 & 20 \\
\hline $\mathrm{N} 2 \mathrm{~V} 2 \mathrm{~K} 3$ & 23 & 10 & 30 \\
\hline N2V3K1 & 23 & 7 & 10 \\
\hline $\mathrm{N} 2 \mathrm{~V} 3 \mathrm{~K} 2$ & 23 & 7 & 20 \\
\hline $\mathrm{N} 2 \mathrm{~V} 3 \mathrm{~K} 3$ & 23 & 7 & 30 \\
\hline N3V1K1 & 21 & 8 & 10 \\
\hline N3V1K2 & 21 & 8 & 20 \\
\hline $\mathrm{N} 3 \mathrm{~V} 1 \mathrm{~K} 3$ & 21 & 8 & 30 \\
\hline N3V2K1 & 21 & 10 & 10 \\
\hline $\mathrm{N} 3 \mathrm{~V} 2 \mathrm{~K} 2$ & 21 & 10 & 20 \\
\hline N3V2K3 & 21 & 10 & 30 \\
\hline N3V3K1 & 21 & 7 & 10 \\
\hline $\mathrm{N} 3 \mathrm{~V} 3 \mathrm{~K} 2$ & 21 & 7 & 20 \\
\hline N3V3K3 & 21 & 7 & 30 \\
\hline
\end{tabular}




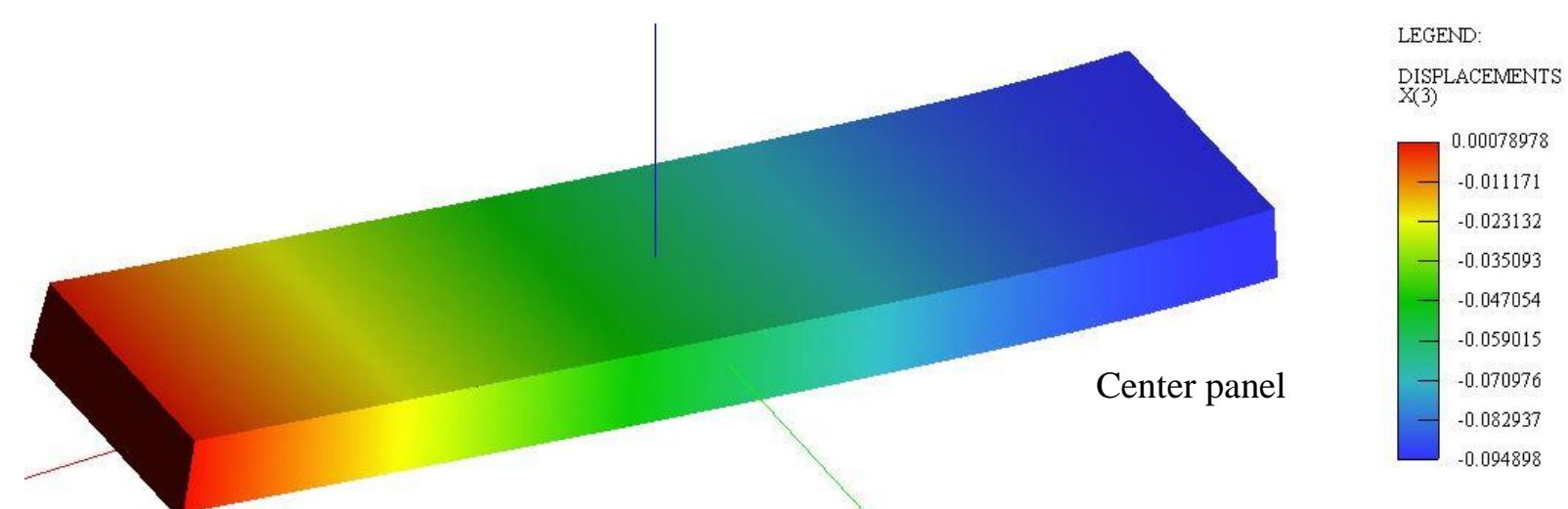

Figure 6: Deflection panel

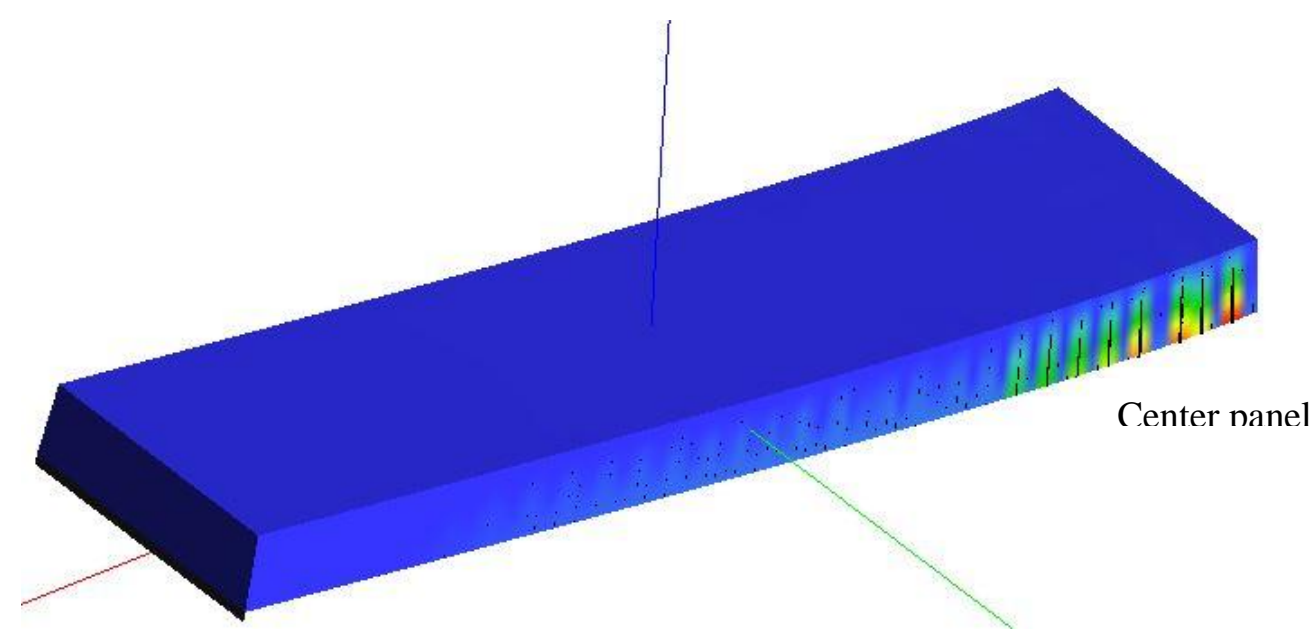

LEGEND: CRACK_WIDTH

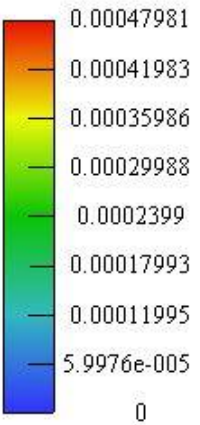

Figure 7: The bending cracks panel

\subsection{Results of parametric analysis}

Behaviour of one of the panels is shown in Fig. 8 where, for illustration, the deflection-load ratio diagram for panel N1V1K1 is shown. For each model, load values and deflections were calculated while reaching limit crack widths according to [5], $\mathrm{w}_{\max }=0,3 \mathrm{~mm}$ (XC3 environment class) and $\mathrm{w}_{\max }=0,4 \mathrm{~mm}$ (max. bar diameter), and load values were calculated while reaching limit deflection values (1 / 100, 1/ 250). For N1V1K1 panel, the calculated values are presented in Table 3. 


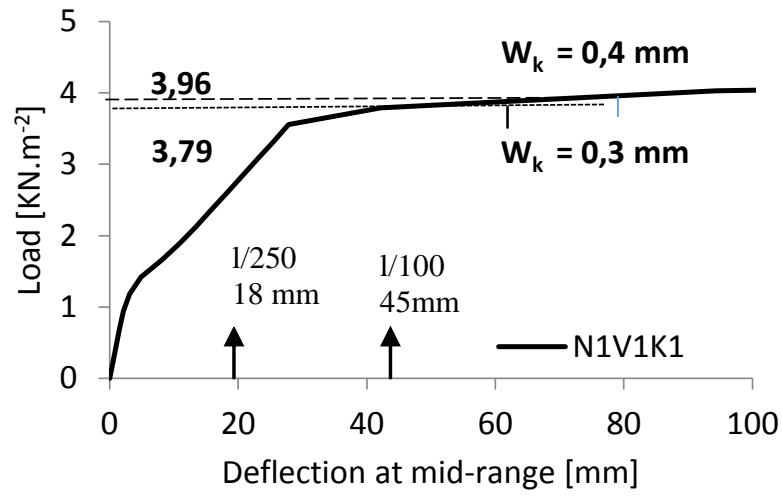

Figure 8: Stress strain diagram -panel N1V1K1

Table 3: Calculated values of load factor and deflection

\begin{tabular}{|c|c|c|c|c|c|c|}
\hline \multirow{2}{*}{$\begin{array}{c}\text { Labelling } \\
\text { panel }\end{array}$} & \multicolumn{4}{|c|}{$\begin{array}{c}\text { Load factor on reaching the limit value } \\
{\left[\mathrm{kN} / \mathrm{m}^{-2}\right]}\end{array}$} & \multicolumn{2}{c|}{$\begin{array}{c}\text { Deflection on reaching } \\
\text { the limit value }[\mathrm{mm}]\end{array}$} \\
\cline { 2 - 7 } & $\begin{array}{c}\text { Deflection } \\
1 / 100= \\
45 \mathrm{~mm}\end{array}$ & $\begin{array}{c}\text { Deflection } \\
1 / 250 \\
=18 \mathrm{~mm}\end{array}$ & $\begin{array}{c}\text { Crack } \\
\mathrm{W}_{\max }= \\
0,3 \mathrm{~mm}\end{array}$ & $\begin{array}{c}\text { Crack } \\
\mathrm{w}_{\mathrm{k}}= \\
0,4 \mathrm{~mm}\end{array}$ & $\begin{array}{c}\text { Crack } \\
\mathrm{w}_{\max }= \\
0,3 \mathrm{~mm}\end{array}$ & $\begin{array}{c}\text { Crack } \\
\mathrm{w}_{\mathrm{k}}= \\
0,4 \mathrm{~mm}\end{array}$ \\
\hline $\mathrm{N} 1 \mathrm{~V} 1 \mathrm{~K} 1$ & 5,26 & 2,58 & 3,89 & 3,96 & 59,57 & 78,94 \\
\hline
\end{tabular}

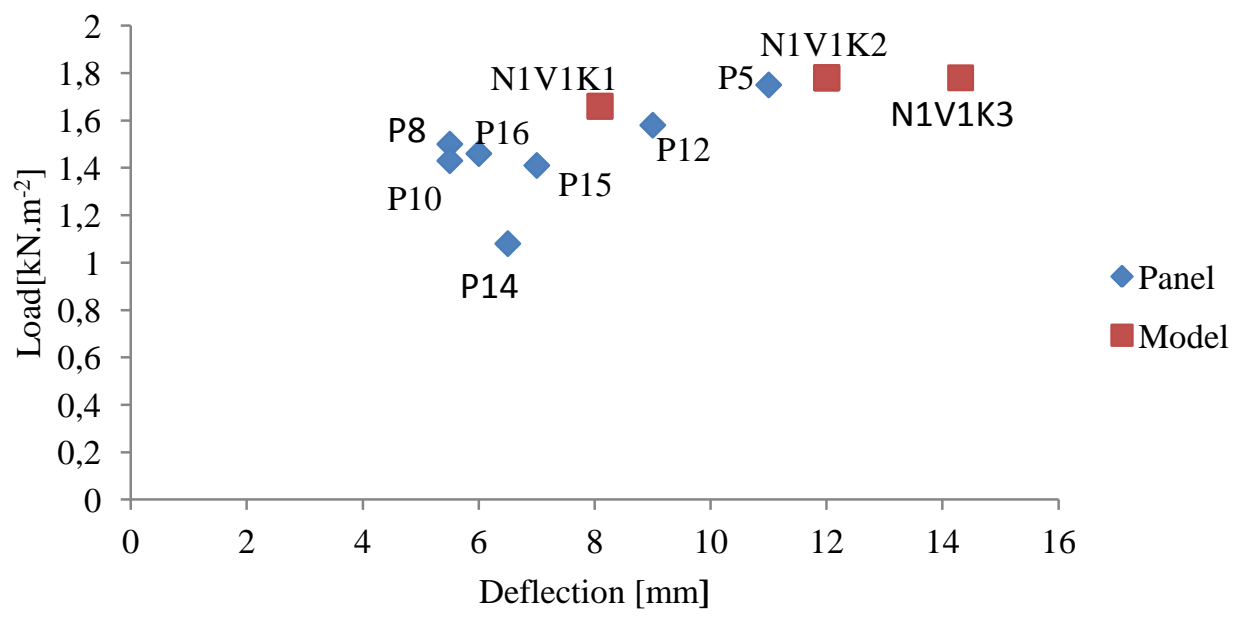

Figure 9: A comparison of cracking limit 


\section{Conclusion}

The parametric study pointed out possible roof panels behaviour from a possible change of chosen parameters point of view. Based on the result analysis of the designed parametric models, it is possible to conclude the following:

- Ultimate crack formation was reached in physical panels at a lower load, which corresponds with a high level of panel degradation (Fig. 9).

- In loading the model, when reaching the limit deflection, the crack width does not exceed a limit value.

- A good correspondence between model and physical panels behaviours was proved while observing the original parameters, which means that ceiling panels resistance is still sufficient from their static behaviour point of view. It was proved that the reinforcement position significantly affects the panel deflection.

Based on the above mentioned findings, it is possible to conclude that the examined ceiling is not in such a critical condition that would inevitably require its removal. However, it is necessary to slow down the degradation process by a suitable reconstruction, and to eliminate the unfavourable impact of the aggressive cow barn environment by suitable means.

\section{References}

[1] Fecko L. \& kol. (1988). Experimentálne overovanie únosnosti strešných železobetónových panelov zobjektu K-174 v Liptovskom Ondreji. Košice: Stavebná fakulta VŠT Košice. (Výskumná úloha R-02-529-811)

[2] Priganc S., Hegedüsová I. (2009). Miera degradácie strešných železobetónových panelov v pol'nohospodárskom objekte. In Speciální betony, Sekurkon Praha. Place of publication: Praha.

[3] Červenka Consulting. (2013). ATENA Program Documentation Part 8, User's Manual for ATENA GiD Interface. The location: http://www.cervenka.cz.

[4] Červenka Consulting. (2012). ATENA Program Documentation Part 1, Theory. The location: http://www.cervenka.cz.

[5] Slovenský ústav technickej normalizácie. (2006). EUROKÓD 2: Navrhovanie betónových konštrukcií - Čast' 1-1: Všeobecné pravidlá a pravidlá pre pozemné stavby. STN EN 1992-1-1. Slovakia. 